\title{
FINANCIAL PROSPECT OF THE WASTE TO ENERGY APPLICATION IN SOLVING THE MOST PROBLEMATIC SOLID WASTE MANAGEMENT IN INDONESIA
}

\begin{abstract}
MOHAJIT
DOI: 10.21163/GT_2019.141.33

ABSTRACT:

Solid waste generation rate in big cities in Indonesia is recorded at $500 \mathrm{t}$ day-1 to 7,000 $\mathrm{t}$ day $^{-1}$. The practice of sanitary land fill technology with a very large volume of solid waste tends to become more complex and becomes difficult in controlling the impact of the resulting environmental pollution. Incineration technology has been proven its implementation in some developed and developing countries. Meanwhile gasification/plasma technology and pyrolysis technology are still limited in the application and are still under development process. Study on the extent of incineration technology in the application for waste management in Indonesia is carried out. The purpose of this study is to look at the financial prospects of incinerator technology applications for solid waste management in Indonesia. The application of incineration technology seems interesting in respect to the technical aspects in reducing significantly the volume of solid waste and as well as in producing a very useful source of electrical energy. On the other hands the financial prospect is also very attractive where the breakeven point, net present value and internal rate of return seem to be bankable on the basis of reasonable tipping fee that is quite affordable for the house hold served.
\end{abstract}

Key-words: Breakeven Point, Internal Rate of Return, Net Present Value, Solid Waste, Waste to Energy.

\section{INTRODUCTION}

Solid waste generation rate in big cities in Indonesia is recorded at $500 \mathrm{t} \mathrm{day}^{-1}$ to 7000 $\mathrm{t} \mathrm{day}^{-1}$. At least 20 cities had been identified to have such that a huge amount of solid waste generation rate. For example, Jakarta has a waste generation of approximately $7000 \mathrm{t} \mathrm{day}^{-1}$, Surabaya records a waste generation of approximately $2000 \mathrm{t} \mathrm{day}^{-1}$, Bandung, Bekasi, and Medan produce approximately $1,500 \mathrm{t} \mathrm{day}^{-1}$ of municipal solid waste. Six other cities recorded a production rate of about $1,000 \mathrm{t} \mathrm{day}^{-1}$ of solid waste, including the city of Tangerang, Depok, Semarang, Palembang, Makassar, and Tangerang Selatan. Other large cities with population less than 1000000 people are predicted to produce waste generation of about $500 \mathrm{t} \mathrm{day}^{-1}$, for example, Bogor, Batam, Pekan Baru, Bandar Lampung, Malang, Denpasar, etc.

Solid waste management by the application of sanitary land fill technology cannot solve the waste problem and tends to create new problems in the increasingly difficult and expensive land procurement in recent years. The availability of land for the development of sanitary land fill within the city is no longer possible, while looking for locations outside the city often arise conflict of interest between the cities. Intensive study by using GIS techniques on the placement suitability of waste sanitary landfill has been conducted also by Manoiu et al. (2013). Furthermore, the practice of sanitary landfill technology with a very large volume of solid waste tends to become more complex and becomes difficult in

${ }^{1}$ Institute of Technology Bandung, Jalan Ganesha 10, Bandung Indonesia, mohajito@ hotmail.com 
controlling the impact of the resulting environmental pollution. Martinát \& Turečková (2016) present theoretical aspects and preconditions of the acceptance of the facilities for generating renewable energy with an emphasis on rural areas. Also, the acceptance of the local anaerobic digestion (AD) plant by its local population was researched. Leachate of municipal waste is considered as a source of contamination and pollution that have a major environmental impact on water resources (Boutera et al., 2012).

Based on the considerations and background as described above it is necessary to adapt efficient and effective technology by applying the technology of waste to energy in order to solve the problem of waste management in Indonesia (Government of Indonesia, 2008; Environmental Health Perspective, 2016). Incineration technology and waste to energy system have been proven its implementation in some developed and developing countries (Meisen and Morgan, 2010). Meanwhile gasification/plasma technology and pyrolysis technology are still limited in the application and are still under development process.

In various literatures explained that waste to energy technology can be developed through two processes, namely biochemical processes and thermal processes. The biochemical process is divided into two processes: anaerobic digestion process to produce methane fuel and fermentation process to produce ethanol fuel. While the thermal process is divided into three types, namely, combustion process, pyrolysis process, and gasification process/plasma.

The combustion process, known as incineration technology, is a combustion process at temperature of around $1,200^{\circ} \mathrm{C}$ with excessive oxygen supply using a burning furnace to generate heat which then the heat can be converted into electrical energy through boilers and turbines. The solid waste burned through the incinerator will be converted into heat and electrical energy or a combination of heat and energy (Combined Heat and Power, CHP).

While pyrolysis process, is a combustion process at temperature of around $1,000^{\circ} \mathrm{C}$ with no oxygen supply using a combustion chamber to produce char and synthetic gas which then can be used as fuel to generate electricity through boilers and or generator sets. The gasification process/plasma is a combustion process at temperature of around $3000^{\circ} \mathrm{C}$ with partial oxygen supply using a plasma reactor to converts organic matter into a syngas (synthesis gas) which is primarily made up of hydrogen and carbon monoxide. A plasma torch powered by an electric arc is used to ionize gas and catalyze organic matter into syngas with slag remaining as a byproduct. The synthesis gas can then be used as fuel for turbine engine or heater.

Study on the extent of incineration technology in the application for waste management in Indonesia is carried out. The purpose of this study is to look at the financial prospects of incinerator technology applications for solid waste management in Indonesia. The application of incineration technology seems interesting in respect to the technical aspects in reducing significantly the volume of solid waste and as well as in producing a very useful source of electrical energy (Department of Environment for Food and Rural Affairs, 2013). Ribeiro and Kimberlin (2010) studied comprehensively on the high efficiency of the combined municipal solid waste and natural gas or ethanol in waste to energy power plants.

\section{MATERIALS AND METHODS}

An incinerator with a capacity of $1,000 \mathrm{t} \mathrm{day}^{-1}$ is a typical waste to energy system that is generally applied to generate electricity of about $12 \mathrm{M}$ Watt. The system consists of 
Incineration Unit, Steam Boiler Unit, Turbine Unit, Generator Set, Cooling Unit, Air Pollution Control System, Wastewater Treatment Unit, Sludge Treatment Unit, Water Supply System, Control System, Trash Storage Bunker, Building and Operation Room, Electricity Transformator, Dump Truck, Heavy Vehicle, and Workshop.

This study will use this type of incinerator where necessary investments include Access Road and Landscaping, Houses, Cars, and Motor Cycles for Officials, and Land Acquisition. Engineering cost estimates was made to predict investment cost of the incinerator system as well as their operational cost. Income is expectedly generated from the tipping fee and the sale of electrical energy generated. Financial analysis was then developed by using a mathematical model to look at a bankability of the investment.

A mathematical modeling for the financial analysis was developed to simulate any condition of the financial aspect in respect to the application and implementation of the incinerator system (Mohajit, 2011; Velten, 2009; Ogata, 1998). Important parameters and criteria for the financial analysis in the model include: Capacity of solid waste input $(\mathrm{t}$ day $^{-1}$ ), In-plant Losses (\%), Tipping fee for solid waste input (IDR $\mathrm{t}^{-1}$ ), Operation Cost (IDR $\mathrm{t}^{-1}$ ), Maintenance Cost (IDR $\mathrm{yr}^{-1}$ ), Investment including VAT (IDR), Investment, VAT and IDC (interest rate during construction) (IDR), Construction Periods (months), Tax after BEP (\%), Interest Rate or Discount Rate (\%), Equivalent Household served $\left(\mathrm{HH} \mathrm{d}^{-1}\right)$, Equivalent Tipping Fee per Household (IDR/month), Energy Tariff from Waste to Energy (WtoE) Turbine (IDR $\mathrm{kWH}^{-1}$ ), IRR guess (\%), Targeted Period of Investment (yr), Targeted IRR (\%), Inflation Rate/Fee and Tariff Increase (\%), Standby Cash for Operation \& Maintenance (months), Tipping Fee Payment Efficiency (\%), Maximum Extended Period of Payment (months), etc. The output parameters of the financial analysis includes: BEP (breakeven point), IRR (internal rate of return), NPV (net present value), and DCR (debt coverage ratio).

\section{RESULTS AND DISCUSSION}

The investment cost as well as the operational cost for the application and implementation of the incinerator system was estimated based on the standard price of the Ministry of Public Work, the Government of Republic Indonesia, No. 03/PRT/M/2013, as depicted in Table 1 and Table 2 (Government of Indonesia, 2013). Others cost include water consumption; fuel subsidy for operational activities; allowance for New Year, Eid Fitri, and bonus; out station allowance (OSA), and allocation for research and development.

The cost for maintenance is estimated at around IDR $66357000000 \mathrm{yr}^{-1}$ including the civil building for around IDR 8,124,500,000.00 per year as well as electrical and mechanical equipment at around IDR 58,232,500,000 $\mathrm{yr}^{-1}$, respectively.

Table 1. Summary of investment cost.

\begin{tabular}{|l|r|}
\hline \multicolumn{1}{|c|}{ Parameter } & \multicolumn{1}{|c|}{ Value in IDR } \\
\hline Investment Cost & $1,477,100,000,000.00$ \\
Engineering Cost & $22,156,500,000.00$ \\
Unpredictable Cost & $73,855,000,000.00$ \\
Total Cost & $1,573,111,500,000.00$ \\
Value Added Tax 10\% & $157,311,150,000.00$ \\
Grand Total & $1,826,434,150,000.00$ \\
\hline
\end{tabular}


The financial analysis for the application of incinerator system is simulated under the following data and assumptions: Capacity of waste input $=1000 \mathrm{t} \mathrm{day}^{-1}$, In-plant Losses $=$ $2 \%$, Tipping fee for solid waste input $=$ IDR 1,553,772 $\mathrm{t}^{-1}$, Operation Cost $=$ IDR 553,772 $\mathrm{t}^{-1}$, Maintenance Cost $=$ IDR 66,357,000,000 $\mathrm{yr}^{-1}$, Investment including VAT $=$ IDR $1,826,434,150,000$, Investment, VAT and IDC (interest rate during construction) $=$ IDR 2,035,623,000,000, Construction Periods $=36$ months, Tax after BEP $=15 \%$, Interest Rate or Discount Rate $=12 \%$, Equivalent Household served $=294,118 \mathrm{HH} \mathrm{d}^{-1}$, Energy Tariff from Waste to Energy Turbine = IDR $1000 \mathrm{kWH} 1$, Inflation Rate/Fee and Tariff Increase = $6 \%$, Standby Cash for Operation and Maintenance $=3$ months, Tipping Fee Payment Efficiency $=97 \%$, Maximum Extended Period of Payment $=3$ months, Loan component $=$ $70 \%$ and equity $=30 \%$, VGF (viability gab funding) component $=49 \%$. Typical solid waste characteristics are presented in the following Table 3.

Table 2. Summary of operation cost.

\begin{tabular}{|c|c|}
\hline Parameter & Value in IDR/ton waste \\
\hline Remuneration & $35,000.00$ \\
Chemicals & $199,000.00$ \\
Electrical Energy & $156,000.00$ \\
Fuel for Extra Heating & $140,350.88$ \\
Others & $23,421.11$ \\
Total & $553,71.99$ \\
\hline
\end{tabular}

Table 3. The typical characteristics of the solid waste in some cities in Indonesia.

\begin{tabular}{|c|c|}
\hline Parameter & Value \\
\hline Generation rate (L/HH/day) & 17 \\
Organic content (\%) & 54 \\
Inorganic content (\%) & 46 \\
Density (kg/L) & 0.20 \\
Water content (moisture) in \% & 70 \\
Ash (\%) & 15 \\
Heat value (kJ/kg) & 3,000 \\
Heat value required for incinerator & 3,800 \\
\hline
\end{tabular}

Due to a lower heat value of the solid waste $\left(3,000 \mathrm{~kJ} \mathrm{~kg}^{-1}\right)$ it is necessary to increase the heat value to around $3,800 \mathrm{~kJ} \mathrm{kg-1}$ as required by the incinerator. In this case diesel is used to increase the heat value of the solid waste from $3,000 \mathrm{~kJ} \mathrm{~kg}-1$ to more or less 3,800 $\mathrm{kJ} \mathrm{kg}^{-1}$. By this fuel for extra heating is required and it will cost around IDR 140,350.88 ton $^{-1}$ solid waste.

Simulation of the financial model results as depicted in the following Table 4 and Fig. 1. From the financial analysis model as depicted in Fig. 1, and Table 4, it can be seen that the investment for the implementation of incinerator system could be paid back within 6.5 yr period and its Net Present Value is quite attractive at around IDR 3,185,900,558,965, with Internal Rate of Return of $30.40 \%$ in the year of 25 th. This financial prospect which looks very good and bankable is mainly due to the support of the $49 \%$ VGF (viability gab funding) intervention (Government of Indonesia, 2012; Government of Indonesia, 2013; Government of Indonesia, 2016), as well as the tipping fee which seems affordable to the house hold served. In this case the house hold served have to pay monthly of equivalent to IDR 158,485 based on the generation rate of the solid waste around $17 \mathrm{~L}_{\text {household }}{ }^{-1} \mathrm{day}^{-1}$. 
Simulation of financial analysis model without intervention of VFG, it seems likely that application of incinerator system for the solid waste management in Indonesia is still feasible as can be seen in Fig. 2 and Table 5. The breakeven point is 8.8 year and its NPV is 2,613,596,209,533, with Internal Rate of Return of $21.58 \%$ in the year of 25 th. By this option the investment is also still bankable.

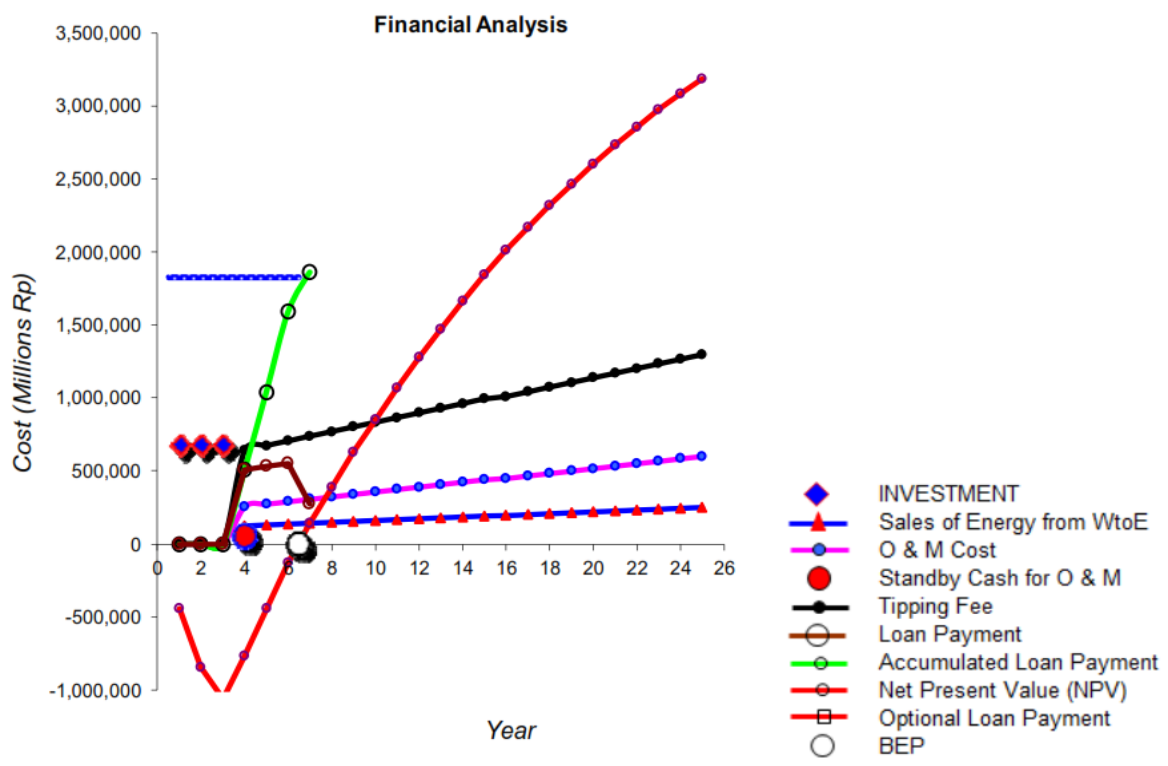

Fig. 1. Result of the financial analysis for VGF $=49 \%$.

Table 4. Resume of the financial analysis.

\begin{tabular}{|c|c|}
\hline Parameter & Value \\
\hline Year period & 10 th \\
DCR & 2.15 \\
NPV (IDR) & $852,311,821,983.24$ \\
IRR & $24.18 \%$ \\
\hline Year period & 25 th \\
DCR & 8.6 \\
NPV (IDR) & $3,185,900,558,965.05$ \\
IRR & $30.40 \%$ \\
Breakeven point (years) & 6.5 \\
VGF & $49 \%$ \\
\hline
\end{tabular}

Table 5. Resume of the financial analysis.

\begin{tabular}{|c|c|}
\hline Parameter & Value \\
\hline Year period & 10 th \\
DCR & 1.23 \\
NPV (IDR) & $280,007,472,551.62$ \\
IRR & $12.31 \%$ \\
\hline Year period & 25 th \\
DCR & 4.93 \\
NPV (IDR) & 2613596209533.43 \\
IRR & $21.58 \%$ \\
Breakeven point (years) & 8.8 \\
VGF & $0 \%$ \\
\hline
\end{tabular}




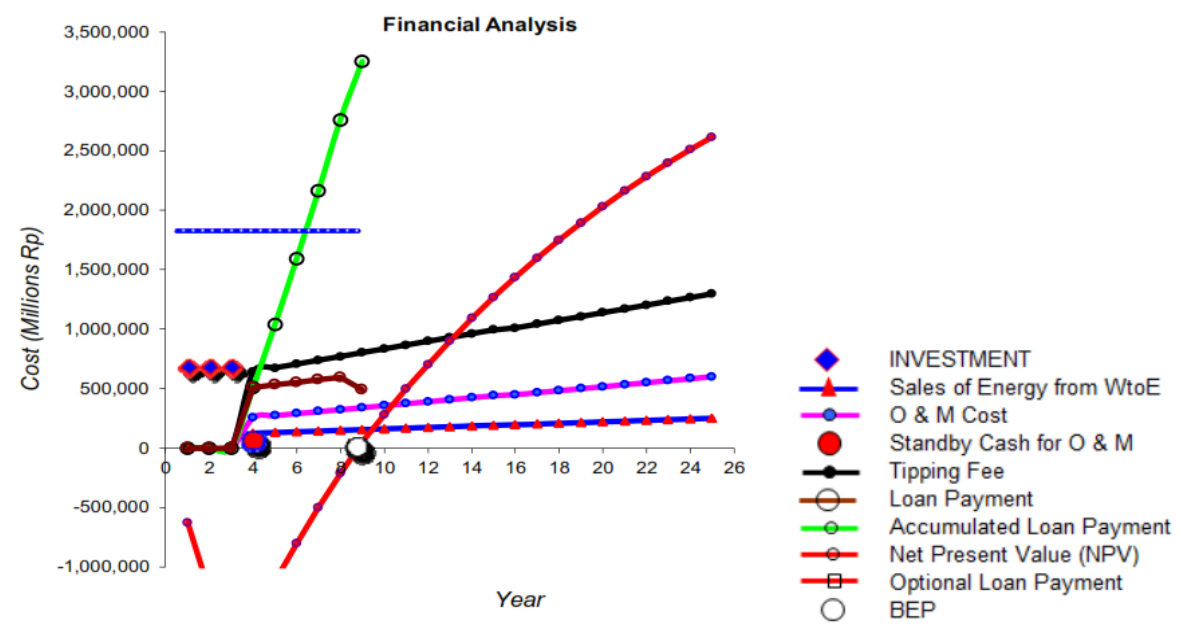

Fig. 2. Result of the financial analysis for VGF $=0 \%$.

\section{CONCLUSIONS}

This study has clearly shown that the application and implementation of waste to energy of the incinerator system for the solid waste management in Indonesia is actually inexpensive. The investment cost of IDR 2,035,623,000,000 is equivalent to IDR 6,921,118 household-1 served. With a reasonable and affordable tipping fee it appears that the application of waste to energy of the incineration system for the solid waste management in Indonesia is financially prospective and bankable to solve the most problematic solid waste management in Indonesia.

\section{ACKNOWLEDGEMENTS}

The author would like to thank to PT. PRATAMA GROUP Jakarta and PT. LAPI ITB GANESHATAMA CONSULTING Bandung for their initiative effort and support in this study on the application and implementation of waste to energy of the incineration system for the solid waste management in Indonesia. Special thank is also directed to Dr. Subekti, SE, MM, the president director of PT. PAL Jaya Jakarta, who invited the author for meaningful discussion in wastewater and solid waste management in Jakarta.

\section{REFERENCES}

Boutera, M., Rouabhia, A., Lakhneche, D. \& Zerek, S. (2012) Wastewater rejections impact on groundwater quality in a semiarid region: case of Tebessa aquifer. Geographia Technica, 1, 1927.

Department for Environment Food and Rural Affair (2013) Incineration of municipal solid waste. Department of Environment for Food and Rural Affairs, Retrieved from: http://www.wtert.co.uk/content/Defra\%20report.pdf [Accessed March 2019]

Environmental Health Perspective (2016) Focus: Emerging Waste-to-Energy Technologies, Volume 124 No. 6, 107-111. Retrieved from: https://www.dx.doi.org/10.1289/ehp.124-A106.

Government of Indonesia (2008) Act No. 18 of 2008 about waste management]. Government of Indonesia. Retrieved from: http://www.bphn.go.id/data/documents/08uu018.pdf [Accessed March 2019] 
Government of Indonesia (2012) Government Regulation No. 81 of 2012 about waste management of household waste and household garbage. Government of Indonesia, Retrieved from: http://www.menlh.go.id/DATA/PP_NO_81_TAHUN_2012.pdf [Accessed March 2019]

Government of Indonesia (2013) Minister of Public Works Regulation No. 03/PRT/M/2013 about the implementation of solid waste infrastructure and facilities in handling household waste and household garbage. Government of Indonesia, Retrieved from: http://ciptakarya.pu.go.id/plp/upload/ Peraturan/Permen_PU_No_3_Tahun_2013__Penyelenggaraan_PS_Persampahan.pdf [Accessed March 2019]

Government of Indonesia (2016) Presidential Regulation No. 18 of 2016 about accelerating the construction of waste-based power plants for 7 major cities. Government of Indonesia, http://www.hukumonline.com/pusatdata/downloadfile/lt56f235bbble72/parent/lt56f23549a0688 [Accessed March 2019]

Meisen, P. \& Morgan, I. P. (2010), Waste-to-energy plants. Global Energy Network Institute, 1-32.

Manoiu, V., Fontanine, I., Costache, R., Pravalie, R. \& Mitof, I., (2013) Using GIS techniques for assessing waste landfill placement suitability. Case study: Prahova County, Romania. Geographia Technica, 8 (2), 47-56.

Martinát, S. \& Turečková, K. (2016) Local development in the post-mining countryside? Impacts of an agricultural ad plant on rural community. Geographia Technica, 11 (1), 53-65.

Mohajit (2011) Financial prospect to the application of high rate water treatment plant system, in Seminar Proceedings: Humboldt Kolleg: Synergy, networking, and the role of fundamental research development in Asean, In conjunction with: International Conference on natural sciences (Icons 2011), Malang Indonesia. July 9-11, 2011. http://jurnal.uii.ac.id/JSTL/article/view/3584

Ogata, K. (1998) System dynamics, New Jersey: Prentice Hall International Inc. 4th edition.

Ribeiro, S. G. \& Kimberlin, T. (2010) High Efficiency Waste to Energy Power Plants Combining Municipal Solid Waste and Natural Gas or Ethanol, Proceedings of the 18th Annual North American Waste-to-Energy Conference, NAWTEC18, May 11-13, 2010, Orlando, Florida, USA, 1-7

Velten, K. (2009) Mathematical Modeling and Simulation: Introduction for Scientists and Engineers, Copyright (C) 2009 WILEY-VCH Verlag GmbH \& Co. KGaA, Weinheim, ISBN: 978-3-52740758-8, pp 1-45. 